\title{
Cultural Landscape Design in Nigeria during the Pre-Colonial, Colonial and Twenty-First Century.
}

\author{
Philip Ayuba Salome Kolo* Elijah Emmanuel Ayuba S. I Shuaibu \\ Department of Architecture, School of Environmental Technology, Federal University of Technology. P.M.B 65, \\ Minna, Niger State. Nigeria \\ * E-mail of the corresponding author: Salome.kolo@,futminna.edu.ng
}

\begin{abstract}
Landscape is an integral part of man's environment and the term in relation to a place may invoke the creation and experience of multiple meanings. This research investigates the relationship between landscapes in Nigeria during the precolonial, colonial and the twenty-first century. It looks at the influences of colonialism on landscape design, which seeks to find out how Nigeria has fared in its land use planning. The research highlighted the continued importance of historically constituted landscape upon which present-day activities in Nigeria are performed, and also considered the existing relationships of the present to the past. This paper through intensive review of relevant literature - books, journals and seminar papers amongst other documents, critically examined the factors that best answer the objectives of the study. The paper also outlines outdoor spaces that connect individuals to their social, economic and religious or cultural activities. It reviewed reasons that necessitate the proper organisation or arrangement that landscape design is concerned with. The paper recommended adequate implementation of town planning laws such as the active participation of the masses.
\end{abstract}

Keywords: architecture, cultural landscape, design, environment

DOI: $10.7176 / \mathrm{CER} / 11-2-08$

Publication date:March $31^{\text {st }} 2019$

\section{Introduction}

The term "landscape" in its earliest use in the medieval times referred to an area owned by a lord or inhabited by a group of people, while its modern usage emanated from the $16^{\text {th }}$ century when Italian and Dutch painters used it as a representation of scenery (Whyte, 2002). According to Falk \& Balling (2010) they discovered that historic patterns of landscape design worldwide reveal some striking parallels in the use and organization of certain landscape elements particularly in large gardens and estates, where aesthetic preferences could most easily be expressed.

Landscaping encompasses an environment in which man lives and grows in response to both biological material as well as physical needs (Agboola, et. al, 2016). Nigeria is a country that parades numerous traditional building design concepts and landscape elements at different regions of climatic conditions, socio-economic and cultural background. Rikko \& Gwatau (2011), referred to the term traditional as an accepted and practiced cultural heritage gained from generation to generation. Therefore, designs in traditional architecture reflect the cultural lifestyle of the people and represent the symbols of the heritage of the residents (Agboola, et. al, 2016). In addition, form and function of housing and landscaping vary with people's customs and culture, as an aftermath of what the populace considered as important.

Landscape architecture as defined by Dee (2001) is the spatial organisation of outdoor places to meet human needs while protecting or enhancing the natural environment and processes. Thus, landscape design aims to create places that meet social, environmental, cultural, aesthetics and practical requirements through the manipulation of the material environment. This points to the fact that the goal of landscape design is to achieve balance in the environment. Marsh (2010) supports this point maintaining that one reason for landscape design is to guide development toward environmentally responsive planning and design practices that creates a harmony between land use and the environment, yielding sustainability in the long run.

This research therefore examines landscape design practices in Nigeria during the precolonial, colonial and the twenty-first century. It investigates the influences colonialism had on landscape design and land use planning in Nigeria. The study also highlights the continued importance of historically constituted landscape upon which present-day activities in Nigeria are performed. 


\section{Literature Review}

The provision of outdoor spaces is an integral contributor to the overall quality of architectural environment (Fadamiro, 2000). Marsh, (2010) opined that landscape is that part of the terrain which is modified according to a set of cultural plans. Idris (2014), alluded that land tenure in pre-colonial Northern Nigeria, was at best a feudal system. Communal lands are vested in traditional rulers or community heads while, family lands are vested in family heads whose legal status was that of a trustee to allocate, reallocate and supervise the use of such lands (Adeyinka et al, 2006).

This old land tenure system in Nigeria apart from being an obstacle to land classification, has continued to create an obstacle to commercial agriculture, wildlife protection, forest resource development, recreational development for people, and wilderness preservation (Usoh, 2006), which leaves no planned system for rural development. Adeyinka et al (2006) stated that the approaches of traditional settlement development gradually gave way to colonial approaches when Lagos was annexed as a British colony in 1861 and the promulgation of the Town Improvement Ordinance in 1863 to control development and urban sanitation in Lagos.

\subsection{Landscape Design in Pre-Colonial Nigeria}

Pre-colonial Nigeria consisted of kingdoms, chiefdoms and city-states; these kingdoms survived and defended themselves based on what the landscape provided: visibility, walls, agriculture, and mining. There was need therefore, to plan how these resources were to be used. Culturally there were norms that ensured efficient management of the landscape. These norms manifested in city planning, agricultural practices, cultural ceremonies and festivals.

In pre-colonial Nigeria, cities were designed with spaces, and in Northern Nigeria they functioned as market places, horse riding spheres, areas preserved for durbar usually situated in the front of the emir's palace or other designed areas of the town (Dmochowski, 1990). Islam played fundamental roles in the spatial organization of economic, social, and religious spaces in the cities. The differences in the perception of built space between the settled nomadic cultures, and sedentary ones, like the Hausa and Kanuri, were lessened in part by Islam, which helped introduce Fulbe built forms into Hausa society (DeLancey, 2012).

DeLancey (2012) maintained that in the Fulbe built forms, the homestead is divided into two basic areas, a western cattle enclosure and an eastern residential area, separated by the rope running down the middle to which calves are tied at night. It is commonly thought that these two areas are gender specific. The eastern household area is a feminine domain, while the cattle corral is a masculine domain. As the once nomadic Fulbe settled into sedentary communities in the late $18^{\text {th }}$ and early $19^{\text {th }}$ centuries, the concept of the wuro expanded from the single encampment to the larger unit of the city (DeLancey, 2012).

According to Kawu et al (2012), Zaria was founded as capital of the old Hausa kingdom of Zeg Zeg (Zazzau) in about 1536. The city has served as a political, administrative, and market centre for several hundred years. The physical expression of the city is through its walls, roads and paths, the market place, the mosque and the emir's palace.

In western Nigerian, open space served as grounds for festivals, recreation and areas of open market (Oja Oba) while in the eastern part of Nigeria they function as debating grounds (Ilo), point of meetings and wrestling grounds, usually large open areas shaded by Awbu trees with wide spread branches and abundant foliage which adds more to the scenic value of the town (Dmochowski, 1990). In the 14th century, it was discovered that Benin had the world's largest hand-dug moat, measuring 1,200 kilometres long and 20 metres height. This was conserved and declared as a world heritage site (Ekhaese and Amole 2014).

\subsection{Landscape Design in Colonial Nigeria}

Adeyinka et al, (2006) explained how Lord Luggard's 1900 land proclamation in respect to the title of land in northern Nigeria and the introduction of indirect rule brought about a change in land administration and settlement development in Nigeria. For the first few decades of colonial rule, prisoners were employed in relatively large gardens where they produced vegetables for consumption. The British also started a number of tree-planting initiatives to procure local sources of fresh citrus and other tropical fruits, many of which were later linked with windmill schemes.

In the colonial era, the town planning ordinance of 1928 recognized the importance of open space use, after the outbreak of bubonic plague; buffer zones were setup to be used around buildings in the Government Reserved Areas (GRA), to stop the spread of diseases. The recent town planning laws of 1992, backed by decree 88, also encourages the setting aside of open spaces. The preparation of a ten-year Plan of Development and Welfare $(1946-1956)$ by the government marked the beginning of a systematic planning. One of the major schemes of 
the plan was Town Planning and Village Reconstruction. The Colonial Government consequently enacted the Nigerian Town and Country Planning Ordinance (No. 4 of 1946) to provide for the planning, improvement and development of different parts of the country through planning schemes initiated by planning authorities based on the 1932 British Town and Country Planning Act (Dmochowski, 1990; Adeyinka et al, 2006).

Late in his reign the emir of Kano, Abdullahi, impressed by British gardens, began British-style gardening on a large scale in the western and eastern fields of the cikin gida. His gardening engulfed the traditional spaces of slave women and introduced the notion and practice of gardening and farming for leisure. Later, during the reign of Alhaji Ado Bayero, he spatially formalised children's play areas by building a playground on the abandoned ruins of the former concubine ward of Dutsen babba (Nast, 1994).

\subsection{Landscape Design in Post-Colonial and $21^{\text {st }}$ Century Nigeria}

In the $21^{\text {st }}$ century, landscape planning is driven by the concept of sustainability. The concept of sustainable development can be traced to the energy crisis and the environmental pollution concern in the 1970s (Marsh, 2010). The green building movement in the United States of America (USA) originated from the need for more energy efficient and environmentally friendly construction practices. Building green spaces have certain benefits such as environmental, economic, and social. Advantages and benefits of green housing are stipulated to include improvement of indoor air quality, increase in energy efficiency and waste reduction, in which all plants, animals and other forms of life are able to exist in an ecosystem without any external aid or interference. This design, which is sustainable in approach integrates the life-cycle of the building, with green practices employed with a design purpose to create a synergy amongst the practices used (Adedeji, 2006).

In a study carried out by Atolagbe and Fadamiro (2006), in Akure South-west Nigeria, they discovered that plants and structural materials were sparingly utilized in the open spaces. They attributed this to the inability of the government in encouraging the landscaping of the open spaces in the city centre and the lack of awareness and interest of the people in landscaping their environment. Adedeji, (2006) also, in his study of worship centres in Akure posits that colonial influences are responsible for proper landscaping of orthodox churches which are at variance with the latter generations of churches that are indigenous in setting and source. He stated that site and architecture work together for the full realisation of intended use.

The intervention of the 'city beautification programmes' carried out by the state governments years back was not sustained because of the lack of effective provisions of maintenance and policy backup for the decisions. Atolagbe and Fadamiro (2006), assert that the possibility for the sustainable landscaping of the urban open spaces in Nigeria to achieve its goals is currently far from being realized. The outdoor environment needs to be consciously organized for social relationships for the city inhabitants.

More recent studies however, reveal that some of the most notable beautification projects in Lagos involved the conversion of road medians and areas around cloverleaf interchanges to mini parks (Ogunsote et al, 2011). These spaces under overhead bridges and other public spaces such as road medians had been taken over by rubbish dumps, squatters, illegal shanty structures and in some instances, served as open air toilets (Ogunsote et al, 2011). These spaces have now been converted to car parks and properly landscaped or converted to mini parks and gardens. Examples include bridges along the Marina, Muriokunla, the Gani Fawehinmi Park, the M.K.O. Abiola Gardens and even the Bar Beach have been beautifully landscaped, shown in figures 1 and 2.

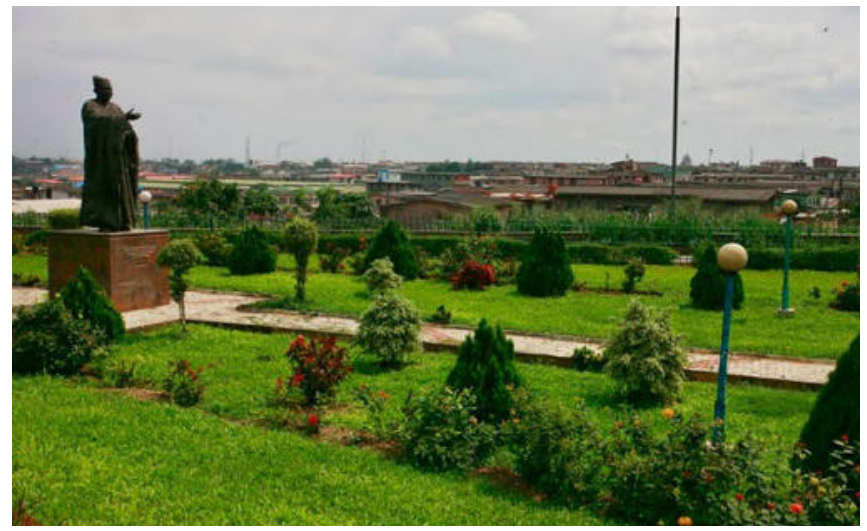

Figure 1. MKO Abiola Garden

(https://www.nairaland.com/attachments/445445_abiola2_jpg59019d377ac44ab2987197b5b1d18451) 


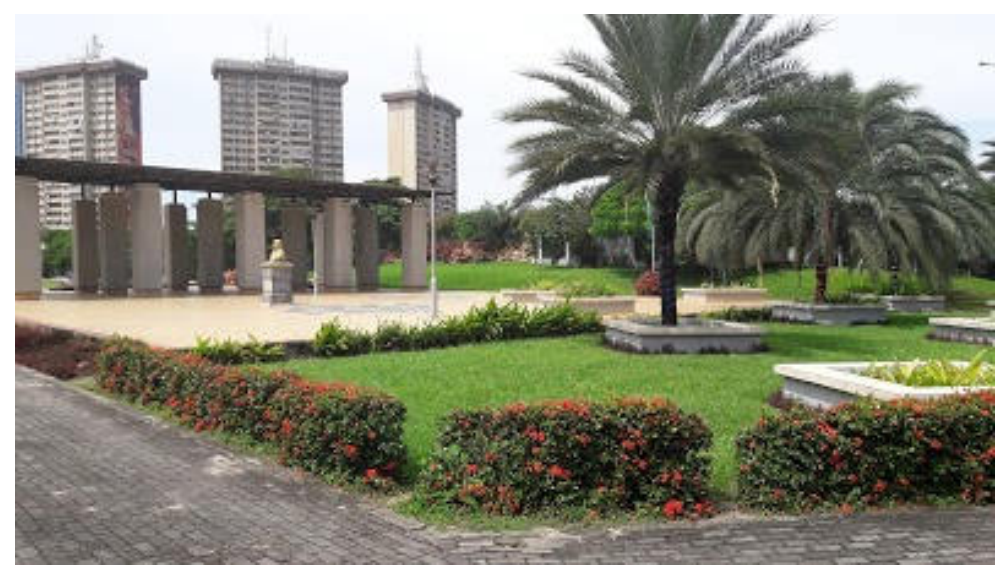

Figure 2. Landscape features at Muriokunla

(https://h3.googleusercontent.com/p/AF1QipMqcvUlxKksGfRfUchdQXRByKNrefOj7nGPVyI=s1600-w400)

Many pedestrian walkways have been constructed along major roads while drains have been provided to reduce the problems of flooding (Ogunsote et al, 2011). Although most of the sidewalks are not bicycle or disabledfriendly, pedestrians are now safer. The introduction of several bus stop stands with an artistic touch of cantilevered canopies provides welcome shade for commuters.

\section{Methodology}

This study relied entirely on historical documents and previous researches into the subject matter. Though there is insufficient data on landscape design or the process of such designs in Nigeria, however, there is adequate data on the historical development of cities and their planning process. The research also looked into land administration and management to ascertain the agricultural, mining, economic and commercial activities that affected landscape design in the periods under investigation. This helped to put landscape design in the various periods into perspective, to better understand their landscape design requirements.

\section{Discussions}

Outdoor spaces connect individuals to activities such as social, economic and religious or cultural. This is why proper organization or arrangement of landscape design features is important. Since landscape design deals with the organization and arrangement of outdoor spaces, it transcends the individuals' own environment and becomes the very fabric on which cities are built. The "wuro" of the Fulanis for instance, transcends the place of the heard to a homestead and even the city. The division of the homestead into two basic areas, a western cattle enclosure and an eastern residential area, separated by a rope running down the middle to which calves are tied at night, shows the relationship between the cattle and the individual family.

Every landscape changes with time and varies from place to place. This can be attributed to natural processes or adaptation of use, thus, time has a direct consequence on landscape. Bad land use planning can have an adverse effect on the environment thus leading to the degradation of the environment. Land tenure, which is a product of socio-economic reality, affects landscape design. For instance, land fragmentation, a prevailing tenure system in Nigeria, has made land use implementation difficult especially in the rural areas.

Islam has a profound effect in planning and design of cities such as Kano, Zaria and Sokoto. These effects became conspicuous only after the jihad in the early $19^{\text {th }}$ century in which the mosques assumed prominence as the centre of the city while the palace is subordinate to the east of it. Farming for pleasure was introduced in the colonial era by the British and was adopted by the elite in the society (Kelly and Norman, 2003).

Environmental pollution and the energy crises in the $1970 \mathrm{~s}$ in the United States birthed the concept of sustainability which involves the manipulation of materials in the natural environment to bring about efficiency in energy consumption while at the same time reducing the production of waste, thereby bringing about a balance in the ecosystem. It is also noteworthy that institutions and establishments founded in the colonial era integrated planned landscaping and still maintain proper landscaping compared to their indigenous counterparts 
of the precolonial era. Socio-economic conditions in the $21^{\text {st }}$ century, have led to open spaces being encroached upon and are disappearing due to population and economic pressures which also called for 'city beautification programmes. However, these programmes were not sustained owing to policy and institutional failures.

\section{Conclusion and Recommendation}

It is clear that due to population explosion after independence, residential land use increased which led to the disappearance of open spaces thereby leading to a decline or absence of landscape design in most areas. In the $21^{\text {st }}$ century, information is a major component of decision making process thus in Nigeria land management and administration play a greater role in landscape design because land use planning and landscape design depend so much on information about land and its resources. However, there is also need to improve the land use administration and harmonization of the roles of various levels of land use management agencies with adequate provisions for citizens and stakeholders participation in the planning process.

The implementation of town planning laws through special programmes such as public awareness to enlighten people on land use, will help in emphasizing open spaces, which will in turn improve the quality of life of the urban dwellers. It will also control urban expansion, where loss of biodiversity will also be minimized. Landscape designers should ensure there is extensive tree planting, provision of safe pedestrian and disabledfriendly walkways, bicycle routes, and better control of bill boards, which should inform the landscaping in this twenty-first century Nigeria.

\section{References}

Adedeji, Y. M. D. (2006). "Outdoor space planning and landscape qualities of religious centres in Akure, Nigeria”, Inter-World Journal of Management and Development Studies 2(1), 57-67.

Adeyinka, S. A., Omisore, E. O., Olawuni, P. O., \& Abegunde, A. A. (2006). "An evaluation of informal sector activities and urban land use management in south western Nigeria", Proceedings of Shaping the Change XXIII FIG Congress Munich, Germany, 2006.

Agboola, O. P., Rasidi, M. H., \& Said, I. (2016). "Residents' Contribution towards Improving Physical Quality of Neighbourhood Open Spaces in Multi-Cultural Community of Nigeria", Journal of Advanced Research in Social and Behavioural Sciences 2(1), 75-92.

Alabi, M. O. (2009). "Revitalizing urban public open spaces, through vegetative enclaves in Lokoja, Nigeria". Journal of Geography and Regional Planning, 2(3), 51.

Atolagbe, A. M. \& Fadamiro, J. A. (2006). "Urban environmental sustainability: A challenge to effective landscaping in Nigeria". Journal of Architecture and Built Environment 34(1), 44.

Dee, C. (2001). "Form and Fabric in Landscape Architecture: A Visual Introduction", Taylor \& Francis Group.

DeLancey M. D. (2012). "The Spread of the Sooro Symbols of Power in the Sokoto Caliphate", Journal of the Society of Architectural Historians 71 (2), 1-18.

Dmochowski, Z. R., (1990). "An Introduction to Nigerian Architecture- Northern Nigeria”, London, Ethnographica Ltd., 1-20.

Ekhaese, E. N. \& Amole, B. (2014). "Benin domestic architecture "a tabula rasa" for transition: from preindependence to contemporary architecture", International Journal of Social Sciences and Entrepreneurship, 1(9), 264-287.

Fadamiro, J. A. (2000). "Outdoor spaces and their landscape qualities - a comparative analysis of three neighbourhoods in Lagos, Nigeria", Journal of Urban and Environmental Research 2(1), 55-67.

Falk, J. H. \& Balling, J. D. (2010). "Evolutionary influence on human landscape preference", Environment and Behaviour 42(4), 479-493.

Idris A. M. (2014). “Tenure and Administration of Land in Northern Nigeria”, Kaduna: Joyce Graphic Printers \& Publishers Company.

Kawu, A. M., Ahmed, A., \& Usman, A. S. (2012). "Learning from tradition: elements and practice of urban development control in Zaria, City, Nigeria", An International Journal Contemporary Res 2(7), 205-213.

Kelly, K., \& Norman, N. (2007). "Historical archaeologies of landscape in Atlantic Africa”, In D. Hicks, 1. McAtackney, G. Fairclough (Eds.) Envisioning landscape: situations and standpoints in archaeology and heritage, 
172-193. CA: Left Coast Press.

Marsh, W. M. (2010). "Landscape planning environmental applications", $5^{\text {th }}$ ed, John Wiley \& sons, Inc.

Nast, H. J. (1994). "The impact of British imperialism on the landscape of female slavery in the Kano palace, northern Nigeria", Journal of the International African Institute, 64(1), 34-73.

Ogunsote, O. O., Adedeji, Y. M. D., \& Prucnal-Ogunsote, B. (2011). "Combating environmental degradation through sustainable landscaping in emerging mega cities: a case study of Lagos, Nigeria", Proceedings of 24th World Congress of Architecture UIA2011 Tokyo 25, 16-21.

Rikko, L. S. and Gwatau, D. (2011). "The Nigerian architecture: The trend in housing Development" Journal of Geography and Regional Planning 4(5), 273-278.

Usoh, N. U. R. (2006). "The Need for Land Reforms in Nigeria", Inter-World Journal of Management and Development Studies 2(1), 154-162.

Whyte, I. D. (2002). "Landscape and History since 1500”, 12-14. Reaktion Books 